\title{
Trust in Executive Search - the Client's Perspective
}

\author{
Juergen Rohrmeier \\ FOM University of Applied Sciences Munich \\ Pape Consulting Group AG
}

\author{
Tom Egan \\ Waterford Institute of Technology \\ Thomas Peisl \\ Munich University of Applied Sciences
}

A key aspect to successful headhunters is developing trust, yet how such trust is developed in the crucial initial exchange phase of a relationship with clients is an under-researched area. This study adopts a quantitative approach (survey of 175 clients) and the results show that perceived trustworthiness does have a significant impact on subsequent trust behaviour, with risk perception and trust propensity moderating this relationship. Such findings have important implications for headhunters (in terms of hiring and developing talent) and can assist clients to make better selection decisions.

\section{INTRODUCTION AND RESEARCH CONTEXT}

As a result of corporate scandals and financial, economic and political crises around the world trust has become more important than ever. Trust has long been subject of social sciences, philosophy, and psychological studies with an increasing focus on trust in the organizational and business context since the 1980s (Rousseau et al., 1998). Despite this heightened interest in trust a common definition or conceptualisation of trust does not exist. Trust is a dynamic, multi-dimensional and multi-faceted construct (Bell et al., 2002; Blomqvist, 1997; Dietz and Den Hartog, 2006; McEvily and Tortoriello, 2011; McKnight et al., 2002a).

As an experienced headhunter, the author was piqued as to why some consultants within this field were more successful than others and had witnessed how important the establishment of trust in the crucial initial exchange phase of a new client relationship was for building a long-term relationship. Headhunting has a secretive, covert reputation regarding data protection and ethical behaviour (Britton and Ball, 1999; Clark, 1993; Hofmann and Bergert, 2014) and indeed is still confronted with the question. "A trustworthy headhunter? Isn't that a contradiction?". The clients of headhunters are asked to pay a considerable upfront fee and, in the author's own experience, would not do this unless they perceive the headhunter as trustworthy at the initial exchange point. This led to this study into which factors establish this kind of trust and how it can be demonstrated, influenced and developed. The study is focused on a particular type of service called retained-based search where headhunters offer an exclusive agreement to 
identify, approach and select possible candidates that are employed in companies of relevance (Britton et al., 1992; Britton and Ball, 1999; Clark, 1993). To offer a headhunter such an exclusive agreement requires "a need for trust" on the part of the client (Britton and Ball, 1999, p. 143) and, if successful, can lead to a long-term relationship with the headhunter

This paper is organised as follows: A literature review of trust and trustworthiness with a focus on the headhunting business, culminating in the conceptual framework for this study, a brief outline of the methodology adopted, and the results obtained from a quantitative analysis of survey-based data. The key findings and the relevant implications from both a theoretical and practice perspective are discussed.

\section{LITERATURE REVIEW}

Many definitions of trust exist such as the "confidence in or reliance on some quality or attribute of a person or thing." (Oxford English Dictionary, cited by Zaheer et al., 1998, p. 143) and Rousseau et al.'s (1998) definition of trust as "a psychological state comprising the intention to accept vulnerability based upon positive expectations of the intentions or behaviour of another." (p. 395). Some scholars distinguish trust from trustworthiness such as Hardin (1996) who argues that "establishing and supporting trustworthiness is the best device for creating trust" (p. 29). Gefen et al. (2003, p. 3) elaborate on this distinction when they posit that "trustworthiness is a characteristic of the trustee, while trust is the trustor's willingness to engage in risky behaviour that stem from the trustor's vulnerability to the trustee's behaviour". For this study which focuses on how trust is initially created in a business relationship, it is the perception of trustworthiness that influences the trustor to trust, i.e. to engage in risky behaviour. This led to a review of various conceptual models and studies on how trustworthiness can be perceived. A three-fold characterisation of trustworthiness antecedents has become the dominant model for conceptualizing trustworthiness in organizational research (Mayer et al., 1995; McEvily and Tortoriello, 2011). A particularly appealing element of this concept is that trustworthiness has the potential to influence business success. Thus, Barney and Hansen (1994) consider trustworthiness to be an important source of competitive advantage. In their seminal article, Mayer et al. (1995) explain a dyadic trust model in the organisational context, introducing influencing factors on both parties of a trust relationship, trustor and trustee, with the critical addition of vulnerability and trust propensity. This article proposes a framework for dyadic trust in organisations focusing on antecedents of trustworthiness of the trustee, so that the trustor can take the risk (given a certain level of trust propensity) to show trust behaviour (=to trust). They use ability, benevolence and integrity to describe trustworthiness. Ability refers to the trustor's perception that the trustee can accomplish the specific task at hand effectively. Benevolence refers to the trustor's perception that the trustee cares for the trustor and acts in their best interests. Integrity refers to the trustor's perception that the trustee is committed to an acceptable set of values or principles. The authors provide a theoretical framework explaining how perceived trustworthiness and trust propensity generate trust that, influenced by the level of perceived risk, leads to risk taking in relationships and respective behavioural outcomes. Due to its focus on perceived trustworthiness and the distinction between trustworthiness, risk perception and trust outcomes, the author has chosen this model as a basis for this study.

In the headhunting industry interpersonal trust has a stronger effect on a trustor's commitment than inter-organisational trust, due to the proximity and direct interaction with the headhunter. This is in line with the findings of Zaheer et al. (1998) who postulate that even between organisations it is the individuals who trust or as Vanneste (2016) posits: "...it is people who trust - not organisations." (p. 7). Within this industry, the necessity of trust in the relation between the search consultancy and the clients is highlighted by Britton and Ball (1999); furthermore, Konecki, (1999, p. 562) found that "building trust is an extremely important aspect of work in the headhunting business". It is acknowledged that headhunting is a rather secretive, covert and intangible type of consulting service and that how it exactly works is not necessarily broadly known in the population. Clark (1993) and Britton and Ball (1999) explain that because of the nature of this service and the asymmetric information in the process, there is an inherent possibility of opportunistic behaviour in the beginning (adverse selection) or during the project (moral 
hazard). For clients, this means a remarkable risky environment with high costs of failure. In the context of this billion Euro business where trust is known to play an important role, little is known on how trust is initially formed. Trust, or rather the perception of trustworthiness, seems to be an important, if not necessary ingredient for mutual success. Establishing a better understanding of how trustworthiness is perceived, and what the impact of perceived trustworthiness exactly is on trust behaviour, is a relevant research question both for academic and practical business reasons.

\section{RESEARCH AIMS/CONCEPTUAL FRAMEWORK}

This study is looking at the impact of perceived trustworthiness on trust behaviour, in the trust formation phase between headhunters (trustees) and clients (trustors). The main research question is: How does perceived trustworthiness of the headhunter by clients influence their trust behaviour in the headhunting context?

In distinguishing between trust, the perception of trustworthiness and actual trust behaviour, the study draws from the work of Mayer et al. (1995) and Hardin (1996). Trustworthiness is measured via three antecedents: competence (ability), responsiveness (benevolence) and integrity. Other variables of interest include risk and trust propensity (Chiu and $\mathrm{Ng}$, 2015; Frazier et al., 2013) and some specific aspects in the context of headhunting. Building on the model from Mayer et al. (1995), a framework has been developed which describes the assumed relationships between perceived trustworthiness (=independent variable) and trust behaviour (=dependent variable) with potential moderating and mediating variables. This conceptual framework is shown in figure 1.

\section{FIGURE 1}

\section{CONCEPTUAL FRAMEWORK}

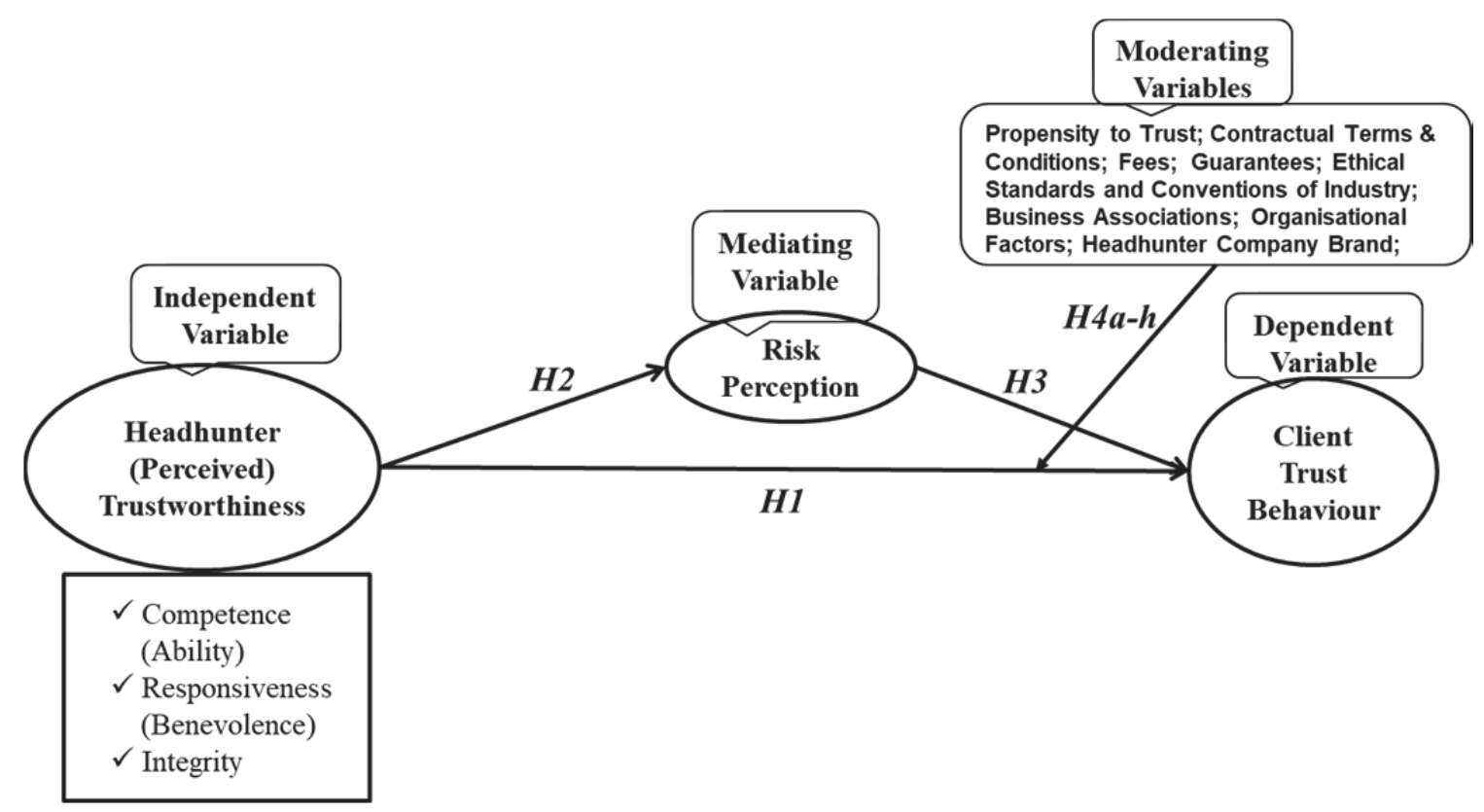


The following hypotheses are formulated to statistically test the model:

\section{TABLE 1 HYPOTHESES OVERVIEW}

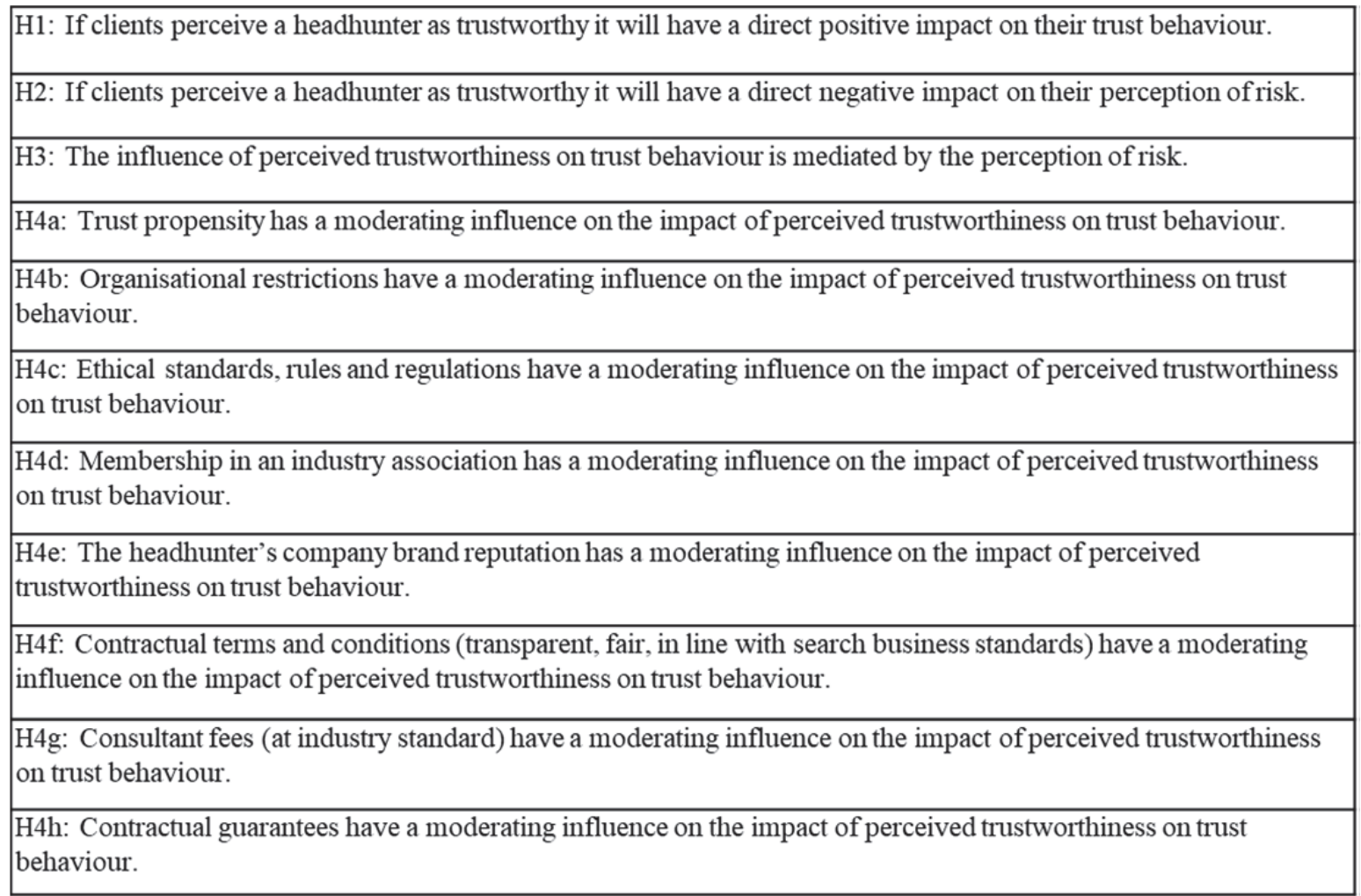

The first hypothesis (H1) focusses on the main research question, the direct impact of perceived trustworthiness on trust behaviour. Following research on trustworthiness (e.g. Becerra et al., 2008; Jiang et al., 2016; Schilke and Cook, 2015), it is assumed that this impact is positive, that a higher degree of perceived trustworthiness is more likely to create trust behaviour. The second hypothesis (H2) considers the impact of perceived trustworthiness on risk perception. Following research proving that trust reduces the perception of risk (Jarvenpaa et al., 2000; Yousafzai et al., 2003), it is assumed that the impact of perceived trustworthiness on risk perception is negative, i.e. more trustworthiness leads to less risk perception. The third hypothesis (H3) covers the possibility of risk perception as a mediator in the relation between perceived trustworthiness and trust behaviour. The fourth hypothesis (H4a-h) is describing the various additional influencing factors which are proposed to moderate the relationship between perceived trustworthiness and trust behaviour. 


\section{METHODOLOGY}

The author conducted a self-administered web-based survey with specifically designed questions. The perception of trustworthiness (independent variable) is measured through five items on each of the three antecedents: competence (ability), responsiveness (benevolence) and integrity. Trust behaviour (dependent variable), risk perception (possible mediating variable) and trust propensity (possible moderating variable) are measured with four to five items. All five-point Likert-type scales are based on already existing validated scales, adapted towards the specific context of headhunting (with the exception of the generic construct trust propensity). Single-item questions were asked about moderating factors such as terms and conditions (including fees and guarantees), reputation of headhunter firm, membership in an industry association, organisational restrictions and ethical rules/conventions. To test representativeness of the results, additional questions were asked related to demographics such as gender, organisational size and industry as well as the number of headhunter contacts. The demographic items were selected because of the availability of market data in Germany (BDU, 2017; BPM, 2015). An open-ended question allowed for feedback and commentary. Ethical approval was obtained through the appropriate ethics committee, and all participants gave their informed consent prior to their inclusion in the study. The author's company (a renowned, well established, mid-size retained-based boutique executive search firm based in Munich) was to select participants for this study and from a potential population of 1,049 possible participants 206 responses came back, of which 175 were completed (=18.4 per cent valid response rate).

\section{RESULTS}

88 per cent of the respondents $(N=175)$ had three or more headhunter contacts. The gender distribution $(N=175)$ displayed 70 per cent male and 30 per cent female respondents. Responses included all organisational sizes, with 77 per cent between 100 and 20,000 employees $(N=175)$. All industries were represented, with the majority coming from the TIMES industries (28 per cent, $N=174$ ). In comparing these results with market data, the sample can be considered sufficiently representative to the target population. All scales were tested for reliability and validity. Internal consistency was good to very good with Cronbach alphas between .75 and .94. Regression data confirm that trustworthiness $(M=3.67$, $S D=.69, N=174)$ is making a significant unique contribution $(r=.69$, Beta $=.87, p<.001)$ to the prediction of trust behaviour $(M=3.46, S D=.87, N=174)$. The coefficient of determination $\left(R^{2}=.47\right)$ shows a high effect size of $47 \%$. Hierarchical regression on the impact of trustworthiness on trust behaviour when the moderators are controlled for confirms the significant contribution of trustworthiness on trust behaviour $(r=.69$, Beta=.76, $p<.001)$. Hypothesis one is supported, as shown in Table 2 which summarises the regression results with trustworthiness as independent variable. 
TABLE 2

REGRESSSION RESULTS WITH TRUSTWORTHINESS AS INDEPENDENT VARIABLE

\begin{tabular}{|c|c|c|c|c|}
\hline \multicolumn{5}{|c|}{ Regression Results (Trustworthiness as independent variable) } \\
\hline Variable & Constant & $\beta$ & $R^{2}$ (change) & $F$ (change) \\
\hline Perception of Trustworthiness ${ }^{\mathrm{a}}$ & .28 & $.69(.07)^{* * *}$ & .47 & $153.35 * * *$ \\
\hline Trust Propensity ${ }^{\mathrm{a}}$ & \multirow{8}{*}{1.15} & $.45(.07)^{* * *}$ & \multirow{8}{*}{$.30(.24)$} & \multirow{8}{*}{$\begin{array}{c}8.67 * * * \\
(83.01 * * *)\end{array}$} \\
\hline 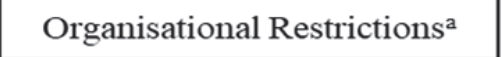 & & $-.24(.06)^{* *}$ & & \\
\hline $\begin{array}{c}\text { Contractual Terms and } \\
\text { Conditions }^{\mathrm{a}}\end{array}$ & & $.15(.10)$ & & \\
\hline Fee at Industry Standard ${ }^{\mathrm{a}}$ & & $-.11(.16)$ & & \\
\hline $\begin{array}{c}\text { Headhunter Provides } \\
\text { Guarantees }^{\mathrm{a}}\end{array}$ & & $.03(.09)$ & & \\
\hline Ethical Standards ${ }^{\mathbf{a}}$ & & $-.03(.08)$ & & \\
\hline Industry Association ${ }^{a}$ & & $.03(.06)$ & & \\
\hline Headhunter company reputation ${ }^{2}$ & & $.27(.07)^{* * *}$ & & \\
\hline \multicolumn{5}{|c|}{$\begin{array}{l}\text { }{ }^{2} \text { Dependent variable: Trust Behaviour } \\
\text { Standardised betas presented. Standard Error in parentheses. } \\
* p<.05 ; * * p<.01 ; * * p<.001\end{array}$} \\
\hline
\end{tabular}

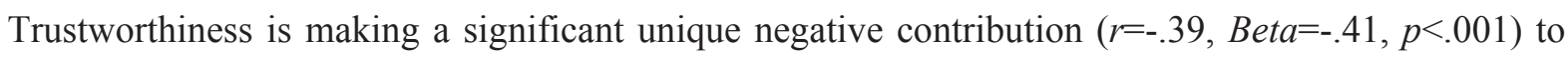
the prediction of risk perception $(M=3.45, S D=.72, N=174)$, with an effect size of $15 \%$. Hierarchical regression on the impact of trustworthiness on risk perception when the moderators are controlled for confirms the significant contribution of trustworthiness on risk perception $(r=-.39, p<.001$, Beta $=-.31$, $p<.01)$. Hypothesis two is supported.

Risk perception is making a significant negative contribution $(r=-.35$, Beta $=-.41, p<.001)$ on trust behaviour, with an effect size of $12 \%$. Hierarchical regression on the impact of risk perception on trust behaviour, when the moderators are controlled for, confirm a significant negative contribution of risk perception on trust behaviour $\left(r=-.35, p<.001\right.$, Beta=-.24, $p<.01, R^{2}$ (change) $\left.=.04\right)$. The impact of risk perception on trust behaviour when trustworthiness is controlled for shows no significance, though $(r=-$ $.35, p<.001$, Beta $=-.11, p>.05, R^{2}$ (change)=.01). In short, the analysis shows inconclusive results in terms of statistical significance with risk perception as mediator, and Hypothesis three is questioned. This led the author to test risk perception as a moderator and it was found that it had a significant moderating influence $(p<.01)$.

The regression analysis controlling for the moderators provides mixed results. Trust propensity $(M=3.47, S D=.92, N=174)$ makes a significant contribution on trust behaviour $(r=.40$, Beta $=.37, \beta=.40$, $p<.001)$ and when it is controlled for as moderator $(r=.40, p<.001$, Beta $=.13, \beta=.14, p<.05)$ between trustworthiness $(r=.69$, Beta $=.76, \beta=.60, p<.001)$ and trust behaviour. Hypothesis 4 a is supported. Other moderators contributing with statistical significance to trust behaviour are organisational restriction $(r=-$ $.20, p<.01$, Beta $=-.14, \beta=-.20, p<.05, M=3.44, S D=1.21, N=174)$ and headhunter company brand and reputation $(r=.19, p<.01$, Beta $=.26, \beta=.27, p<.001, M=3.52, S D=.88, N=173)$. However, the mean scores suggest that contractual terms and conditions $(M=4.08, S D=60, N=174)$ and providing guarantees $(M=4.14, S D=.67, N=172)$ are of high importance. In testing hypotheses $4 \mathrm{~b}-\mathrm{h}$, the results were inconclusive, therefore hypotheses $4 \mathrm{~b}-\mathrm{h}$ are not supported. 
Figure 2 shows the resulting statistical diagram.

FIGURE 2

FINAL STATISTICAL DIAGRAM

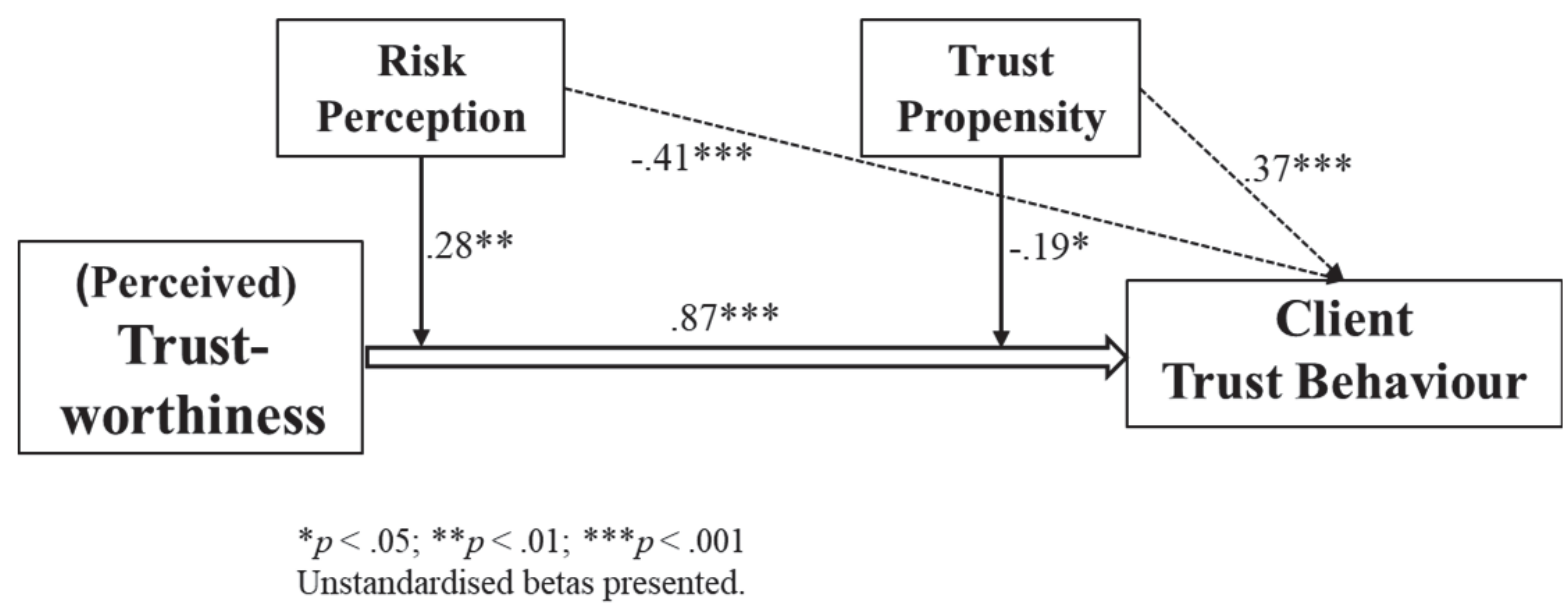

\section{DISCUSSION OF KEY FINDINGS}

\section{Hypothesis One}

It was found that the perception of trustworthiness does have a significant direct positive impact on trust behaviour $\left(\mathrm{r}=.69 ; \mathrm{B}=.87 ; \mathrm{R}^{2}=.47, \mathrm{p}<.000\right)$, and this confirms previous studies on the importance of perceived trustworthiness for creating trust in a business environment (Becerra et al., 2008; Bell et al., 2002; Dreiskämper et al., 2016; Jiang et al., 2016; Poech and Peisl, 2012). Clients want to be in contact with competent, responsive and integer headhunters to constitute trust behaviour. They want to rely on the headhunter's knowledge and relevant expertise of their respective business, industry and positions as well as their professional expertise and experience. They want the headhunter to respond in a timely manner, to listen actively, to communicate openly and honestly and they expect them to be interested in a longerterm relationship, beyond the actual search project. They want to rely on the headhunter's ethical behaviour, on their fairness, flexibility and discreetness and a confidential handling of offered company information and documentation, as the following open-ended quotes confirm:

A good headhunter is well prepared, asks the right questions and listens carefully. Competence is for me and our company extremely important - industry competence as well as headhunting competence.

There are headhunters I enjoy working with. Expect them to be committed, experienced, not-overpromising and have fair commercials.

\section{Hypotheses Two and Three}

The role of risk perception on the relationship between perceived trustworthiness and trust behaviour turned out to be somewhat different to what was originally envisaged. Initially, it was found that the perception of trustworthiness has a significant negative impact on the perception of risk, supporting hypothesis two. The role of risk perception on trust behaviour has been an academic debate about whether it is a mediator or a moderator (Gefen et al., 2003). Becerra et al. (2008, p. 708) found that the relationship between trustworthiness and the actual risk taking is not mediated by the willingness to take risk, and this study confirmed this finding; however, it did confirm risk perception as having a significant moderating role. The definition of headhunting for this study includes the elements of exclusivity and a 
retainer fee paid upfront. There is considerable dependence on the headhunter's engagement and a financial risk involved for clients (Britton and Ball, 1999; Clark, 1993). While the impact of trustworthiness is too strong to allow for mediation, the perception of risk is important enough to influence the effect size of that impact - the higher the perception of risk the more important is the perception of trustworthiness. This suggests that things can become complicated when money enters the equation, as is illustrated in the following quotes:

I was screwed twice by headhunters, i.e. I paid a retainer and they didn't do anything.

Unfortunately, we only had negative experiences with headhunters so far. Too many mediocre and not well-educated candidates are advertised with a lot of praise, who then also turn out to be too expensive - this is not trust-building.

\section{Hypothesis Four}

The results show a significant strong positive impact of trust propensity on trust behaviour and confirm trust propensity as a moderator. Hypothesis $4 \mathrm{a}$ is supported. The higher the trust propensity scores, the lower is the impact of perceived trustworthiness on trust behaviour. Although the perception of trustworthiness will still have a significant influence on trust behaviour, a very high level of trust propensity can create trust behaviour even without solid information/perception of trustworthiness. Significance and effect size are a bit surprising. In a professional business environment, one doesn't necessarily expect the individual personality disposition to trust to play such an important role. The possibility of being too trusting, sometimes referred to as the "dark side of trust" (Gargiulo and Ertug, 2006; Skinner et al., 2014), needs to be considered. As explained above headhunting allows for possible opportunistic behaviour (Britton and Ball, 1999; Clark, 1993). For clients, there is the risk of paying the retainer and not getting any returned service. Therefore, trust propensity should not mean to blindly trust but rather to be diligent in perceiving indications of a headhunter's trustworthiness, as some quotes suggest:

The added value through the close proximity to and knowledge about the respective market needs to be obvious right from the beginning.

A decisive factor for a cooperation is the personal contact and references. That is the basis on which a trustful cooperation can develop.

At the end of the day headhunting is a very personal business. After the initial contact there might be some additional influencers in the further course of a project, but in the beginning, people meet and make decisions on that basis, so that trust is formed. This is supported by respondents' feedback:

I prefer to repeatedly work with the same individual headhunter not matter where he or she is employed.

If you are satisfied with the performance of a headhunter and developed a trustful relationship you intend to work together with him for a long time even if he'll work for another company.

The business with headhunters is a people-to-people business. If there is trust on both sides it doesn't matter where the headhunter is employed. 
Table 5 presents a summary of the results of hypothesis testing via regression analysis.

\section{TABLE 5}

\section{HYPOTHESES SUMMARY OF RESULTS}

\begin{tabular}{|c|c|}
\hline $\begin{array}{l}\text { H1b: If clients perceive a headhunter as trustworthy it will have a direct } \\
\text { positive impact on their trust behaviour. }\end{array}$ & Supported \\
\hline $\begin{array}{l}\text { H2b: If clients perceive a headhunter as trustworthy it will have a direct } \\
\text { negative impact on their perception of risk. }\end{array}$ & Supported \\
\hline $\begin{array}{l}\text { H3b: The influence of perceived trustworthiness on trust behaviour is } \\
\text { mediated by the perception of risk. }\end{array}$ & $\begin{array}{l}\text { Not Supported (however risk perception is } \\
\text { supported as a moderator) }\end{array}$ \\
\hline $\begin{array}{l}\text { H4a: Trust propensity has a moderating influence on the impact of } \\
\text { perceived trustworthiness on trust behaviour. }\end{array}$ & Supported \\
\hline $\begin{array}{l}\text { H4b: Organisational restrictions have a moderating influence on the } \\
\text { impact of perceived trustworthiness on trust behaviour. }\end{array}$ & Not Supported \\
\hline $\begin{array}{l}\text { H4c: Ethical standards, rules and regulations have a moderating } \\
\text { influence on the impact of perceived trustworthiness on trust behaviour. }\end{array}$ & Not Supported \\
\hline $\begin{array}{l}\mathrm{H} 4 \mathrm{~d} \text { : Membership in an industry association has a moderating influence } \\
\text { on the impact of perceived trustworthiness on trust behaviour. }\end{array}$ & Not Supported \\
\hline $\begin{array}{l}\text { H4e: The headhunter's company brand reputation has a moderating } \\
\text { influence on the impact of perceived trustworthiness on trust behaviour. }\end{array}$ & Not Supported \\
\hline $\begin{array}{l}\text { H4f: Contractual terms and conditions (transparent, fair, in line with } \\
\text { search business standards) have a moderating influence on the impact of } \\
\text { perceived trustworthiness on trust behaviour. }\end{array}$ & Not Supported \\
\hline $\begin{array}{l}\text { H4g: Consultant fees (at industry standard) have a moderating influence } \\
\text { on the impact of perceived trustworthiness on trust behaviour. }\end{array}$ & Not Supported \\
\hline $\begin{array}{l}\text { H4h: Contractual guarantees have a moderating influence on the impact } \\
\text { of perceived trustworthiness on trust behaviour. }\end{array}$ & Not Supported \\
\hline
\end{tabular}

A summarising comment about how to successfully work with a trustworthy headhunter is thankfully provided by a respondent:

What are the most important success factors in working with headhunters: they understand the industry (preferably worked in this industry); own a reliable network in the industry; have an authentic, trustworthy and reliable personality; show good and responsive communication behaviour and a solid knowledge of human nature; use solid methods but are also creative; so, a trust relationship is built that ideally can be further enhanced to a trusted advisor status.

\section{CONCLUSION AND RECOMMENDATIONS}

The study has created new academic and business insight into the role of trust in today's world of business, with specific focus on the context of headhunting. The conceptual framework, based on an adaptation of the model by Mayer et al. (1995), contributes to theory by adding previously unanswered research on distinguishing between perceived trustworthiness, trust and trust behaviour in headhunting. The findings can help to explain why some headhunters are more trusted than others and important learnings and messages are now summarised. 


\section{The Initial Client Decision to Engage a Headhunter is Based on the Perception of Trustworthiness of the Headhunter}

In the initial phase, the information available to clients considering the use of a headhunter is limited and trust has yet to be established. Furthermore, whether somebody is indeed trustworthy or not, can only be found out in the course of a relationship or cooperation when through mutual experience and observed behaviour trustworthiness is proven. That means in the beginning of that relationship it is the perception of trustworthiness that constitutes trust behaviour (Becerra et al., 2008). This suggests that clients should concentrate more on the perceived trustworthiness in this initial exchange rather than the financial details of the relationship as this can be the real competitive advantage (Barney and Hansen, 1994). With the theoretical foundation of three antecedents of perceived trustworthiness and their description via a validated questionnaire, this has now become a model for practical implementation. The items can be used to describe how trustworthiness is perceived, they can be used to measure the perception of trustworthiness and they can be used to influence trustworthiness behaviour. Furthermore, client firms should make their recruiters aware of the importance of perceived trustworthiness and train them accordingly.

This finding applies equally to headhunters as it does to clients. It implies that headhunters can improve their success probability by understanding the mechanisms behind being perceived as trustworthy, and through that, influencing trust behavior (Becerra et al, 2008). Headhunters will achieve the perception of trustworthiness only if they fulfil the three antecedents of perceived trustworthiness. Anytime search firms make selection decisions when hiring search consultants or when promoting or developing their own talent, they can use the 15 items as a requirement profile or training plan. They can train their talent to focus more on the perception of trustworthiness, make them understand how important this is and what it exactly means, while at the same time taking care about fees and contracts for clients. Both, individual headhunters and search firms can proactively show aspects of perceived trustworthiness in their presentations (website, brochures, client presentations and any other documentation). In this way headhunters can be trustworthy (again) and the term "a trustworthy headhunter" does not have to be a contradiction any longer.

\section{Trustworthy Headhunters Can Become Business Partners for Clients}

Clients can make their initial decisions based on the perception of trustworthiness and use contractual agreements to reduce the risk involved. However, the perception of trustworthiness extends beyond the initial exchange as clients are interested in a partnership with headhunters, so that they don't have to explain the company or the industry and respective positions again and again. Clients want to rely on the headhunters' competence, their responsiveness and goodwill and their integrity. Fees and contractual terms need to be defined and agreed upon, but then become a secondary priority if trust is established. This leads to true business partnership, which clearly is a benefit to both sides. Headhunters can also be consultants (Britton et al., 1992): they can help in defining the job profile and competency requirements, they can serve as a source of market research, they can help in analysing and maybe improving the recruitment and selection procedures, they can help in questions about employment contracts and can coach the candidate (=the new employee), at least through the onboarding process. This is summarised by one respondent who stated that a 'trustworthy headhunter is someone behaving as a real business partner'.

\section{Clients Should Note That Their Own Trust Propensity Can Influence the Relationship Between Perceived Trustworthiness and Trust Behaviour}

As trust propensity is proven to be a significant moderator in the impact of perceived trustworthiness on trust behaviour (Frazier et al., 2013; van der Werff and Buckley, 2017), clients should be aware of their own personal inclinations to trust and question their intentions by supportive information on how they perceive trustworthiness in a headhunter. Awareness for the influence of their own disposition to trust (trust propensity) should be created, so that decisions are always based on conscious observations and perceptions. Although there is never a guarantee, co-operations with headhunters might then have a 
higher probability of success. Indeed, both headhunters and clients can be more successful by understanding the importance of trustworthiness in constituting trust behaviour in the context of headhunting. This can lead to trust and a trusting relationship.

\section{Successful Headhunter-client Relationships Require Constant Efforts to Maintain Trust}

Headhunters are dependent on a good network and database of clients and candidates (Britton et al., 2000) to have a successful business. In this regard, there can be a conflict between short-term profitability, which may tempt headhunters to maximise fee income, and long-term goals which are based on trustworthy behaviour. This study suggests that if headhunters or headhunting companies as well as clients focus more on observing trustworthy behaviour, the relationship between headhunters and clients will be more based on mutual trust and on longer-term cooperation.

Trust is not developed easily and can be quickly destroyed. Headhunters can prove to be trustworthy by showing competentence, responsiveness and integrity. If they don't, clients will lose their trust and avoid the contact disappointedly. Trust can then be established and maintained in a long-term relationship. In focusing more on the important human side of headhunting, the headhunting industry can regain its reputation, and this will ensure long-term business success. While it is important to consciously

try to convince clients that one can be trusted, nothing works better than keeping all promises. Some behaviours might help manipulating the attribution of trustworthiness in the short-term (Hawes et al., 1989, p. 7). But over the long term, nothing will earn the clients' trust as effectively as truly being a trustworthy individual - a trustworthy headhunter, indeed.

\section{LIMITATIONS AND FUTURE RESEARCH}

With the focus on the German headhunter market, representativeness is limited as demographic data are only compared to the German market. A degree of variation on concepts of trust and headhunting between national cultures or sub-cultures need to be considered, though (Beaverstock et al., 2010; Britton et al., 1995; Doney et al., 1998).

The study deliberately focussed on the initial phase of contact with headhunters. Although it was explained in the correspondence, some respondents remarked that trust can only develop over time. This is true but looking at the whole trust-building process in the relationship or cooperation with headhunters would have left the original intentions of the research aims (i.e. why some headhunters are more successful in winning clients and candidates than others).

There are other factors which could be included in future studies of this area such as the type of channel of contact used (e.g. cold call vs. reliable references). In short, it is anticipated that this study can be a starting point for more empirical studies in this specific or other related fields. 


\section{REFERENCES}

Barney, J. B., \& Hansen, M. H. (1994). Trustworthiness as a Source of Competitive Advantage. Strategic Management Journal, 15, Special Issue: Competitive Organizational Behavior, pp. 175-190.

BDU (2017, May). Personalberatung in Deutschland 2016/2017' [Online]. Bundesverband Deutscher Unternehmensberater BDU e.V., Bonn, May 2017. Retrieved August 11, 2017, from https://www.bdu.de/media/296193/bdu-studie-personalberatung-in-deutschland-2017.pdf

Becerra, M., Lunnan, R., \& Huemer, L. (2008). Trustworthiness, Risk, and the Transfer of Tacit and Explicit Knowledge Between Alliance Partners. Journal of Management Studies, 45(4), 691-713.

Bell, G. G., Oppenheimer, R. J., \& Bastien, A. (2002). Trust Deterioration in an International BuyerSupplier Relationship. Journal of Business Ethics, 36(1-2), 65-78.

Blomqvist, K. (1997). The Many Faces Of Trust. Scandinavian Journal of Management, 13(3), 271-286.

BPM (2015). Markstudie Headhunting In Deutschland: Studie im Auftrag des Bundesverbandes der Personalmanager (BPM)' [Online]. Petry, T., Hochschule RheinMain, Wiesbaden. Retrieved February 11, 2017, from https://www.bpm.de/sites/default/files/petry_bpm_headhunting_studie_210x297mm_final_web.p df

Britton, L. C., Clark, T. A. R., \& Ball, D. F. (1992). Executive Search and Selection: Imperfect Theory or Intractable Industry? The Service Industries Journal, 12(2), 238-250.

Britton, L. C., Doherty, C., \& Ball, D. F. (1995). Executive Search and Selection in France, Germany and the UK. Zeitschrift für Betriebswirtschaft, 67(2), 219-232.

Britton, L. C., \& Ball, D. F. (1999). Trust versus Opportunism: Striking the Balance in Executive Search. The Service Industries Journal, 19(2), 132-149.

Britton, L. C., Wright, M., \& Ball, D. F. (2000). The Use of Co-ordination Theory to Improve Service Quality in Executive Search. The Service Industries Journal, 20(4), 85-102.

Chiu, W. Y. B., \& Ng, F. F. (2015). Enhancement of organizational commitment through propensity to trust. Engineering, Construction and Architectural Management, 22(3), 272-294.

Clark, T. (1993). The Market Provision of Management Services, Information Asymmetries and Service Quality - Some Market Solutions: an Empirical Example. British Journal of Management, 4(4), 235-251.

Colquitt, J. A., Scott, B. A., \& LePine, J. A. (2007). Trust, Trustworthiness, and Trust Propensity: A Meta-Analytic Test of Their Unique Relationships With Risk Taking and Job Performance. Journal of Applied Psychology, 92(4), 909-927.

Deutsch, M. (1958). Trust and Suspicion. Journal of Conflict Resolution, 2(4), 265-279.

Deutsch, M. (1960). Trust, Trustworthiness, And The F Scale. Journal of Abnormal and Social Psychology, 61(1), 138-140.

Dietz, G., \& Den Hartog, D. N. (2006). Measuring Trust Inside Organizations. Personnel Review, Vol. $35(5), 557-588$.

Doney, P. M., Cannon, J. P., \& Mullen, M. R. (1998). Understanding the influence of national culture on the development of trust. Academy of Management Review, 23(3), 601-620.

Dreiskämper, D., Pöppel, K., \& Strauß, B. (2016). Vertrauen ist gut...: Entwicklung und Validierung eines Inventars zur Messung von Vertrauenswürdigkeit im Sport. Zeitschrift für Sportpsychologie, 23(1), 1-12.

Frazier, M. L., Johnson, P. D., \& Fainshmidt, S. (2013). Development and validation of a propensity to trust scale. Journal of Trust Research, 3(2), 76-97.

Gargiulo, M., \& Ertug, G. (2006). The dark side of trust', in Bachmann, R. \& Zaheer, A. (eds) Handbook of Trust Research, Cheltenham, Gloucestershire and Northampton, MA: Edward Elgar, pp. 165186.

Gefen, D., Rao, V. S., \& Tractinsky, N. (2003). The Conceptualization of Trust, Risk and Their Relationship in Electronic Commerce: The Need for Clarifications. Proceedings of the 36th Hawaii International Conference on System Sciences 2003, IEEE, pp. 1-10. 
Hamori, M. (2002). The Maintenance Of Performance And Quality Standards In Executive Search Firms', Proceedings of the Academy of Strategic and Organizational Leadership, Allied Academics International Conference, Nashville, April 2002, Vol. 7, No. 1, pp. 37-43.

Hardin, R. (1996). Trustworthiness. Ethics, 107(1), 26-42.

Hawes, J. M., Mast, K. E., \& Swan, J. E. (1989). Trust Earning Perceptions of Sellers and Buyers. Journal of Personal Selling \& Sales Management, 9(1), 1-8.

Jarvenpaa, S. L., Tractinsky, N., \& Vitale, M. (2000). Consumer trust in an Internet store. Information Technology and Management, 1(12), 45-71.

Jiang, X., Bao, Y., Xie, Y., \& Gao, S. (2016). Partner trustworthiness, knowledge flow in strategic alliances, and firm competitiveness: A contingency perspective. Journal of Business Research, 26(2), 804-814.

Konecki, K. (1999). The Moral Aspects of Headhunting. The Analysis of Work by Executive Search Companies in "Competition Valley". Polish Sociological Review, 128, 553-568.

Kong, D.T., Dirks, K.T., \& Ferrin, D.L. (2014). Interpersonal Trust Within Negotiations: Meta-Analytic Evidence, Critical Contingencies, And Directions For Future Research. Academy of Management Journal, 57(5), 1235-1255.

Lewicki, R. J., McAllister, D. J., \& Bies, R. J. (1998). Trust And Distrust: New Relationships And Realities. Academy of Management Review, 23(3), 438-458.

Lewis, J. D., \& Weigert, A. J. (1985). Trust as a Social Reality. Social Forces, 3(4), 967-985.

Lim, G.-S., \& Chan, C. (2001). Ethical Values of Executive Search Consultants. Journal of Business Ethics, 29(3), 213-226.

Luhmann, N. (1979). Trust and Power/ New York, NY: John Wiley.

Lumineau, F. (2014). How Contracts Influence Trust and Distrust. Journal of Management, 20(10), 1-25.

Mayer, R. C., Davis, J. H., \& Schoorman, F. D. (1995). An Integrative Model of Organizational Trust. Academy of Management Review, 20(3), 709-734.

Mayer, R. C., \& Davis, J. H. (1999). The Effect of the Performance Appraisal System on Trust for Management: A Field Quasi-Experiment. Journal of Applied Psychology, 84(1), 123-136.

McEvily, B., \& Tortoriello, M. (2011). Measuring trust in organizational research: Review and recommendations. Journal of Trust Research, 1(1), 23-63.

McKnight, D. H., Chowdhury, V., \& Kacmar, C. (2002a). The impact of initial consumer trust on intentions to transact with a web site: a trust building model. The Journal of Strategic Information Systems, 11(3), 297-323.

McKnight, D. H., Chowdhury, V., \& Kacmar, C. (2002b). Developing and Validating Trust Measures for e-Commerce: An Integrative Typology. Information Systems Research, 13(3), 334-359.

Poech, A., \& Peisl, T. (2012). The Role Of Trust In The Relationship Between Private Equity Investors And The Family Firm. The Journal of Current Research in Global Business, 23(15), 9-29.

Rotter, J. B. (1967). A new scale for the measurement of interpersonal trust. Journal of Personality, 35(4), 651-665.

Rousseau, D. M., Sitkin, S. B., Burt, R. S., \& Camerer, C. (1998). Not So Different After All: A CrossDiscipline View of Trust. Academy of Management Review, 23(3), 393-404.

Schilke, O., \& Cook, K. S. (2015). Sources Of Alliance Partner Trustworthiness: Integrating Calculative And Relational Perspectives. Strategic Management Journal, 36(2), 276-297.

Skinner, D., Dietz, G., \& Weibel, A. (2014). The dark side of trust: when trust becomes a "poisoned chalice". Organization, 21(2), 206-224.

Van der Werff, L., \& Buckley, F. (2017). Getting to know you: A longitudinal examination of trust cues and trust development during socialization. Journal of Management, 43(3), 742-770.

Vanneste, B. S. (2016). From interpersonal to interorganisational trust: The role of indirect reciprocity. Journal of Trust Research, 6(1), 7-36.

Yousafzai, S., Pallister, J., \& Foxall, G. (2003). A proposed model of e-trust for electronic banking. Technovation, 23(11), 847-860.

Zaheer, A., McEvily, B., \& Perrone, V. (1998). Does Trust Matter? Exploring the Effects of Interorganizational and Interpersonal Trust on Performance. Organization Science, 9(2), 141-159. 